\title{
Population Dynamics of Thrips and Bud Necrosis Virus Disease on Tomato
}

\author{
B. Jamuna ${ }^{1 *}$, M. Bheemanna ${ }^{1}$, A.C. Hosamani ${ }^{1}$, V.N. Ghante ${ }^{1}$, \\ M.R. Govindappa ${ }^{2}$, K. Kavitha ${ }^{3}$ and B. Kisan ${ }^{4}$ \\ ${ }^{1}$ Department of Agricultural Entomology, UAS, GKVK, Bengaluru-560065, India \\ ${ }^{2}$ Department of Plant Pathology, UAS, GKVK, Bengaluru-560065, India \\ ${ }^{3}$ Department of Biotechnology, UAS, Raichur-584102, UAS, GKVK, Bengaluru-560065, India \\ ${ }^{4}$ Department of Horticulture UAS, GKVK, Bengaluru-560065, India \\ *Corresponding author
}

\section{A B S T R A C T}

Studies on population dynamics of thrips on tomato crop were carried out during two consecutive kharif seasons (2016 and 2017). The observations viz., number of adult thrips

\section{Keywords}

Tomato, Thrips,

Miridbug, Disease,

Weather factors

Article Info

Accepted:

04 April 2019

Available Online:

10 May 2019 and associated GBNV disease and natural enemies were recorded at weekly intervals. The results revealed that, thrips activity found throughout the cropping period. The population of thrips was increased gradually from first week after transplanting to flowering and fruit development stage and later it was decreased as crop matures. During 2015-16 kharif crop, maximum thrips population (8.40 thrips/three leaves) was observed during the last week of November and first week of December. Similarly during 2016-17 kharif crop, maximum thrips population (10.30 thrips/three leaves) was observed during third and last week of December. The population of zoopytophagous miridbug, Nesidiocoris tenuis Reuter was found linear with the population of thrips during both the seasons. The percent disease incidence of GBNV on tomato crop was linier with the thrips population during both the seasons. The cumulative disease incidence was $42.50 \%$ and $45.10 \%$ during first and second seasons respectively. Correlation studies indicated that, minimum temperature, rainfall, rainy days and evening relative humidity were found significant negative correlation with the thrips population, while sunshine hours and morning relative humidity found significant positive correlation with the thrips population.

\section{Introduction}

Tomato (Lycopersicon esculentum Mill.) is one of the major and widely grown staple vegetable crop in both tropics and sub-tropics of the world. Though, the area under tomato cultivation is high but the productivity is low due to various biotic and abiotic stress factors. Among the biotic factors, Sucking pests viz., Whitefly (Bemisia tabaci Genn), thrips, aphids (Myzus persicae or Aphis gossypii), mite (Tetranychus spp.) are major threat for tomato cultivation under rainfed area. Of these, recently thrips become emerging pest and viral vector of Groundnut Bud Necrosis Virus (GBNV) disease and causes significant economic damage to the tomato crop.

Three thrips vectors species viz., Thrips palmi Karny Scirtothrips dorsalis Hood and Thrips 
tabaci Lindman transmitting different tospoviruses viz., Groundnut bud necrosis virus (GBNV), Watermelon bud necrosis virus (WBNV), Iris yellow spot virus (IYSV) in various vegetable and field crops in different agro ecosystems in India (Vijayalakshmi, 1994; Mandal et al., 2012; Latha and Hanumantharaya, 2017).

Thrips-tospovirus relationship is very unique because, thrips are the sole insect vectors of tospoviruses. Tospoviruses are not known to be exist in crops or in nature in the absence of thrips vector, the spread of a tospoviruses to large extent depends on the dispersal activity and virus vectoring capacity of local thrips and prevailed weather conditions (Mound, 2002).

GBNV disease causes $60-100 \%$ yield losses in groundnut, chilli and other pulse crops, these are transmitted by $T$. palmi and $S$. dorsalis (Reddy et al., 1983, Rayapati et al., 2012). WBNV disease causes severe yield losses (80-100\%) in cucurbit crops (Singh and Krishnareddy, 1996). IYSV infects on onion and garlic growing region of Maharashtra, Haryana and Punjab and it was vectored by $T$. tabaci Lindmen (Ravi et al., 2006; Pavan et al., 2012).

Field symptoms of GBNV disease are unique, initially yellow faint chlorotic spots appear on young leaves, subsequently necrosis and development of chlorotic rings. In rainy and postrainy seasons, necrosis of terminal bud is the main characteristic symptom, whereas stunting and malformation of leaflets are secondary symptoms.

When the disease occurs at early stage of the crop (before 1 month of transplanting) plants become bushy, stunted and die prematurely, whereas plants tolerate the disease and infection restrict to few branches (after month of transplanting) during later stage of the crop
(Hemalatha, 1999; Anjaneya Reddy et al., 2008; Manjunath, 2008).

Thrips are tiny $(0.5-2 \mathrm{~mm})$, active insect with cryptic living habit, feeds and resides in protective closed areas (unopened shoot buds, flower buds and flowers and fruit calyx) where insecticides difficult to penetrate, hence most of the insecticides are failed to eliminate thrips population (Mandal et al., 2012).

Weather factors viz., temperature, relative humidity and prolonged sunshine hours favours the thrips activity and multiplication and population build-up. Resistant(R) genes require optimum temperature for enzyme expressions, which involve in transcriptional and translational processes. Failing to express $\mathrm{R}$ genes of a resistant variety, it may become susceptible to pathogens (Van der Plank, 1963). Weather factors play crucial role in vector-virus interactions and disease epidemics. Meagre research efforts were made on thrips and GBNV epidemiology in groundnut and chilli but there were no reports on thrips and GBNV disease of tomato crop. In this context the present research plan was formulated to generate the information on thrips population and GBNV disease dynamics and their relation with weather factors on tomato crop.

\section{Materials and Methods}

Experiments on population dynamics of thrips on tomato crop were carried out during two consecutive growing seasons of kharif, 2016 and 2017 at the fields of Department of Agricultural Entomology, Main Agriculture Research Station, UAS, Raichur, Karnataka.

Raichur is situated at North Eastern Dry Zone (Zone-2) of Karnataka between $16^{\circ} 15^{\prime} \mathrm{N}$ latitude, $77^{\circ} 20^{\prime} \mathrm{E}$ longitude and $398.37 \mathrm{~m}$ above mean sea level. The average rainfall is 
$660 \mathrm{~mm}$ confined to monsoon period between June and October with occasional showers during pre-monsoon months of April and May. Mean maximum temperature is more than $30^{\circ} \mathrm{C}$ throughout the year except during December, the Relative humidity (RH) is high during summer months from April to May.

Studies on population dynamics of thrips were conducted on susceptible tomato variety (cv. Arka vikas) which was grown in experimental plot with $200 \mathrm{~m}^{2}$ area. All the recommended package of practices of UAS, Raichur was followed (except plant protection measures) for the crop cultivation.

The seeds of tomato variety (cv Arka Vikas) were sown on raised seed bed under insect free greenhouse. Healthy seedlings were transplanted to the main field after 25 days after sowing.

Observations were made on 30 randomly selected tomato plants at weekly intervals after the first week of transplanting to crop maturity. Mean number of adult thrips on terminal three leaves and associated natural enemies were recorded by tapping the leaves on A4 size white paper. The fallen thrips on paper were counted and collected with fine and moist camel hair brush in $2 \mathrm{ml}$ centrifuge tubes with $95 \%$ alcohol for taxonomic study. The per cent disease incidence of GBNV was also observed and recorded and it was calculated by using the formula

Number of diseased plants

Disease incidence $(\%)=\longrightarrow 100$

Total number of plants examined

The data obtained was subjected to statistical analysis and correlated with weather parameters (minimum and maximum temperature, morning and evening $\mathrm{RH}$, rainfall, rainy day and sunshine hours) during the period of observations. Weather data was obtained from the Meteorology section, MARS, UAS, Raichur campus

\section{Results and Discussion}

\section{Population dynamics of thrips and GBNV disease during $k$ harif, 2015-16}

During kharif season, 2015-16, transplanting of tomato seedlings was done at $39^{\text {th }}$ Standard Meteorological Week (SMW) and observations were started after the first week of transplanting $\left(40^{\text {th }} \mathrm{SMW}\right)$.

Observations revealed that, activity of thrips and miridbug found throughout the cropping period. Maximum thrips population (8.40 thrips/three leaves) was observed during last week of December ( $\left.48^{\text {th }} \mathrm{SMW}\right)$, followed by third week of November (8.00 thrips/three leaves) $\left(47^{\text {th }} \mathrm{SMW}\right)$. Overall population mean of thrips was $4.86 \pm 2.46$ per three terminal leaves.

\section{Miridbug population}

The miridbug, Nesidiocoris tenuis Reuter which was known as zoophytopagous predator (Hinomoto et al., 2015; Bouagga et al., 2018) was found throughout the cropping period. The mean number of miridbug was 4.56 \pm 2.49 per plant, population increasing trend was linear with the thrips population, but reached peak during the later stage of the crop (8.40 miridbug/ plant), whereas thrips population was gradually decreased as crop matures (Table 1).

\section{GBNV disease incidence}

The mean disease incidence of GBNV disease was ranged from 4.90 to $42.50 \%$ during cropping period ( $42^{\text {nd }} \mathrm{SMW}$ to $7^{\text {th }} \mathrm{SMW}$ ). The cumulative disease incidence $42.50 \%$ was observed at later stage of the crop ( $7^{\text {th }}$ SMW) (Table 1). 
Influence of weather parameters on thrips population, GBNV disease and miridbug

The data in the Table 2 revealed that, all the meteorological weather parameters influenced the thrips population, disease incidence and miridbug population.

The weather parameters viz., rainfall ( $\mathrm{r}=-$ $0.588)$ and rainy days ( $\mathrm{r}=-0.603)$ minimum temperature $(\mathrm{r}=-0.475)$ were found highly significant negative correlation with thrips population. Whereas maximum temperature $(\mathrm{r}=-0.305)$ and evening relative humidity $(\mathrm{r}=-$ 0.051) shown non significant negative correlation. While morning relative humidity $(\mathrm{r}=0.259)$ and sunshine hours $(\mathrm{r}=0.076)$ shown non significant positive correlation with thrips population.

When the data subjected to Multiple Linear Regression (MLR) analysis, results revealed that, 80.30 per cent of the thrips population was influenced by weather parameters $\left(R^{2}=\right.$ 0.803) (Table 3). The MLR model was

$Y=2.673-0.024 X_{1}-0.132 \quad X_{2}+0.059 X_{3}-1.980$ $\mathrm{X}_{4}+0.013 \mathrm{X}_{5}+0.035 \mathrm{X}_{6}+0.110 \mathrm{X}_{7}$

The miridbug, $N$. tenuis population was also influenced by all the weather parameters. Minimum temperature $(\mathrm{r}=-0.643)$, rainfall $(\mathrm{r}=$ $-0.570)$, rainy days $(r=-0.565)$, and evening relative humidity $(r=-0.710)$ shown highly significant negative correlation with the thrips population, whereas maximum temperature $(r=0.068)$ and sunshine hours $(r=0.106)$ shown non significant positive correlation (Table 2) with the thrips population.

When the data subjected to MLR analysis, the results revealed that 71.20 per cent of miridbug was influenced by weather parameters $\left(\mathrm{R}^{2}=0.712\right)($ Table 3$)$.

The MLR model was
$\mathrm{Y}=5.618+0.056 \mathrm{X}_{1}-0.134 \mathrm{X}_{2}+0.097 \mathrm{X}_{3}-$ $2.324 \mathrm{X}_{4}-0.022 \mathrm{X}_{5}-0.008 \mathrm{X}_{6}-0.072 \mathrm{X}_{7}$

The GBNV disease incidence was influenced by all the weather parameters under the study. The minimum temperature $(\mathrm{r}=-0.717)$ and evening relative humidity $(\mathrm{r}=-0.600)$ were shown highly significant negative correlation with the disease incidence, followed by rainfall $(\mathrm{r}=0.573)$ and rainy days $(\mathrm{r}=-0.568)$. Maximum temperature $(\mathrm{r}=-0.029)$ and morning relative humidity $(\mathrm{r}=-0.325)$ shown non significant negative correlation, but sunshine hours $(\mathrm{r}=0.600)$ shown non significant positive correlation with the disease incidence (Table 2).

When the data subjected to MLR (Multiple Linear Regression) analysis, the results revealed that 60.90 per cent of the thrips population was influenced by weather parameters $\left(\mathrm{R}^{2}=0.609\right)($ Table 3$)$. The MLR model was,

$\mathrm{Y}=86.791+1.540 \mathrm{X}_{1}-4.316 \mathrm{X}_{2}+3.744 \mathrm{X}_{3^{-}}$ $83.920 \mathrm{X}_{4}-0.176 \mathrm{X}_{5}-0.168 \mathrm{X}_{6}-0.570 \mathrm{X}_{7}$.

\section{Population dynamics of thrips and GBNV disease during kharif, 2016-17}

During kharif 2016-17 season, transplanting of tomato seedlings was done at $41^{\text {st }} \mathrm{SMW}$ and observations were started from the first week after transplanting ( $42^{\text {nd }}$ SMW).

Observations revealed that, thrips and miridbug activity found throughout the cropping period. Maximum thrips population (10.30thrips/three leaves) was observed during $49^{\text {th }}$ SMW. Overall population mean of thrips was $5.83 \pm 17.10$ per three terminal leaves.

\section{Miridbug populations}

Miridbug activity was found throughout the cropping period and population followed the 
similar increasing trend like thrips but the population reached its peak at later stages of the crop. The mean number of miridbug population was $7.32 \pm 3.18$ per plant, peak incidence was noticed during last week of February (12.30/ plant).

\section{GBNV disease incidence}

The GBNV disease incidence was increased gradually from 4.90 per cent to 45.10 per cent ( $42^{\text {nd }}$ SMW to $9^{\text {th }}$ SMW) during the cropping period, cumulative disease incidence was $45.10 \%$ at later stage of the crop.

\section{Correlation between thrips, GBNV disease and $N$. tenius with weather parameters}

Population of thrips had significant negative correlation with maximum temperature ( $\mathrm{r}=-$ 0.485), minimum temperature $(r=-0.605)$, but sunshine hours $(\mathrm{r}=-0.301)$ and evening relative humidity $(\mathrm{r}=-0.099)$ exhibited non significant negative impact. Rainfall $(\mathrm{r}=0.215)$ and morning relative humidity $(\mathrm{r}=0.230)$ shown non significant positive correlation (Table 2).

When the data subjected to MLR analysis, the results revealed that 60.49 per cent of the thrips population was influenced by weather parameters $\left(\mathrm{R}^{2}=0.649\right)$ (Table 3$)$. The MLR model was

$\mathrm{Y}=16.296-0.298 \mathrm{X}_{1}+0.007 \mathrm{X}_{2-}$

$0.013 \mathrm{X}_{3}+0.00 \mathrm{X}_{4}-0.002 \mathrm{X}_{5}-0.073 \mathrm{X}_{6}-0.025 \mathrm{X}_{7}$

The miridbug, N. tenuis population was also influenced by all the weather parameters under the study. Evening relative humidity ( $\mathrm{r}=$ -0.617) shown highly significant negative correlation followed by morning relative humidity $(\mathrm{r}=-0.512)$. Minimum temperature $(\mathrm{r}=0.291)$, maximum temperature $(\mathrm{r}=0.056)$, rainfall $(\mathrm{r}=-0.033)$, and sunshine hours $(\mathrm{r}=$ 0.333 ) were shown non significant and positive correlation with mirid population (Table 2).

When the data subjected to MLR analysis, the results revealed that 61.70 per cent of the mirid population was influenced by weather parameters $\left(\mathrm{R}^{2}=0.617\right)$ (Table 3$)$. The MLR model was

$\mathrm{Y}=14.153-0.250 \mathrm{X}_{1}+0.137 \mathrm{X}_{2^{-}}$ $0.009 \mathrm{X}_{3}+0.00 \mathrm{X}_{4}-0.013 \mathrm{X}_{5}-0.096 \mathrm{X}_{6}-0.224 \mathrm{X}_{7}$.

GBNV disease incidence was affected by all the weather parameters under the study. The parameters viz., evening relative humidity ( $\mathrm{r}=$ -0.689) shown highly significant negative correlation followed by morning relative humidity ( $\mathrm{r}=-0.480)$, but minimum temperature $(\mathrm{r}=-0.031)$ and rainfall $(\mathrm{r}=$ $0.004)$ were shown non significant negative impact. Maximum temperature $(\mathrm{r}=0.188)$, and sunshine hours ( $\mathrm{r}=0.387)$ were shown non significant positive correlation with disease incidence (Table 2).

When the data subjected to MLR analysis, the results revealed that 75.00 per cent of the disease incidence was influenced by weather parameters $\left(\mathrm{R}^{2}=0.750\right)$ (Table 3$)$.

The MLR model was

$\mathrm{Y}=358.983-$

$8.516 \mathrm{X}_{1}+2.868 \mathrm{X}_{2}+0.476 \mathrm{X}_{3}+0.00 \mathrm{X}_{4}-0.493 \mathrm{X}_{5}-$ $2.092 \mathrm{X}_{6}-0.778 \mathrm{X}_{7}$.

Weather conditions play an important role in pest and disease epidemics in different crops, favours the thrips multiplication. Rainfall usually eliminates thrips population and has negative influence on thrips population in different crop plants (Funderburk, 2012). Activity, mobility and multiplication of thrips population were more during favourable weather conditions (i.e., $15-30{ }^{\circ} \mathrm{C}$ temperature range, $70 \pm 10 \% \mathrm{RH}$ and bright sunshine 
hours) (Vijayalakshmi, 1994). Minimum temperature and rainfall were negatively correlated with thrips population in groundnut (Krishnaveni, 1998).

Results of the present findings revealed that, during 2015-16 kharif season, the maximum population of thrips (8.4 thrips/ three leaves) was observed during first and second week of December $\left(48^{\text {th }}\right.$ and $49^{\text {th }}$ SMW respectively), thereafter population started declining (Figure 1). Similarly during 2016-17, the highest population (10.30 thrips/ three leaves) was observed at third week of December $\left(51^{\text {st }}\right.$ SMW) and first week of January ( $1^{\text {st }}$ SMW), thereafter the population started declining (Figure 2). This may be due to peak flowering during December months and minimum rainy days which might have favoured the multiplication of thrips, yellow colour flowers with pollen and nector attracts the thrips towards tomato crop and thereafter, when the crop starts fruiting, thrips population starts declining. The zoophytophagous miridbug, $N$. tenuis presence was suspected to be another reason for thrips decline. Activity of miridbug, $N$. tenuis was linear with the thrips population, it was started from the third week after transplanting and it was increased gradually, reached peak (8.40/ plant) at later stage of the crop ( $7^{\text {th }}$ SMW) during 2015-16. Similarly peak activity (12.30/plant) of miridbug was observed during last week of February $\left(9^{\text {th }}\right.$ SMW $)$ in 2016-17.

Table.1 Population dynamics of thrips and GBNV disease on tomato

\begin{tabular}{|c|c|c|c|c|c|c|}
\hline \multirow{2}{*}{$\begin{array}{l}\text { Observation at } \\
\text { Standard } \\
\text { Meteorological } \\
\text { weeks }\end{array}$} & \multicolumn{2}{|c|}{$\begin{array}{l}\text { Mean number of thrips } \\
\text { per three terminal leaves }\end{array}$} & \multicolumn{2}{|c|}{$\begin{array}{l}\text { GBNV disease } \\
\text { incidence }(\%)\end{array}$} & \multicolumn{2}{|c|}{ Nesideocoris tenuis Reuter } \\
\hline & 2015-16 & 2016-17 & 2015-16 & 2016-17 & 2015-16 & 2016-17 \\
\hline 40 & 0.00 & 0.00 & 0.00 & 0.00 & 0.00 & 0.00 \\
\hline 41 & 1.70 & 1.90 & 0.00 & 0.00 & 1.30 & 1.30 \\
\hline 42 & 2.70 & 3.10 & 4.90 & 4.90 & 1.70 & 3.30 \\
\hline 43 & 4.00 & 4.50 & 9.05 & 9.05 & 2.60 & 5.20 \\
\hline 44 & 4.60 & 4.80 & 12.20 & 11.25 & 2.30 & 5.30 \\
\hline 45 & 5.40 & 5.30 & 12.50 & 18.90 & 2.90 & 6.20 \\
\hline 46 & 6.90 & 6.20 & 18.25 & 20.00 & 3.10 & 6.70 \\
\hline 47 & 8.00 & 8.50 & 23.90 & 22.30 & 3.10 & 7.20 \\
\hline 48 & 8.40 & 8.70 & 28.70 & 25.80 & 3.90 & 7.40 \\
\hline 49 & 8.40 & 10.30 & 32.80 & 38.50 & 3.70 & 7.70 \\
\hline 50 & 7.90 & 10.20 & 36.80 & 40.80 & 4.30 & 7.40 \\
\hline 51 & 7.20 & 9.80 & 36.80 & 43.00 & 5.20 & 7.70 \\
\hline 52 & 6.00 & 8.70 & 37.00 & 43.75 & 5.60 & 8.60 \\
\hline 1 & 5.90 & 7.60 & 37.50 & 44.10 & 5.60 & 9.60 \\
\hline 2 & 5.00 & 6.60 & 37.80 & 44.30 & 6.90 & 9.80 \\
\hline 3 & 4.60 & 5.80 & 38.40 & 44.50 & 7.50 & 9.00 \\
\hline 4 & 3.30 & 4.30 & 39.20 & 44.60 & 7.30 & 9.00 \\
\hline 5 & 2.60 & 3.90 & 42.10 & 44.80 & 7.90 & 11.30 \\
\hline 6 & 2.50 & 3.20 & 42.30 & 45.00 & 7.90 & 11.40 \\
\hline 7 & 2.20 & 3.20 & 42.50 & 45.10 & 8.40 & 12.30 \\
\hline Mean \pm SD & $4.86 \pm 2.46$ & $5.83 \pm 17.10$ & $26.64 \pm 15.07$ & $29.53 \pm 17.10$ & $4.56 \pm 2.49$ & $7.32 \pm 3.18$ \\
\hline
\end{tabular}


Table.2 Correlation between thrips, GBNV disease and Nesidiocoris with different weather parameters

\begin{tabular}{|c|c|c|c|c|c|c|c|}
\hline \multirow[t]{2}{*}{ Particulars } & \multicolumn{2}{|c|}{ Temperature } & \multirow{2}{*}{$\begin{array}{l}\text { Rainfall } \\
\left(\mathbf{X}_{\mathbf{3}}\right)\end{array}$} & \multirow{2}{*}{$\begin{array}{c}\text { Rainy day } \\
\left(\mathbf{X}_{4}\right)\end{array}$} & \multicolumn{2}{|c|}{ Relative humidity } & \multirow{2}{*}{$\begin{array}{c}\text { Sunshine } \\
\text { hours } \\
\left(\mathbf{X}_{7}\right)\end{array}$} \\
\hline & $\operatorname{Maximum}\left(\mathbf{X}_{1}\right)$ & Minimum $\left(\mathbf{X}_{2}\right)$ & & & Morning $\left(\mathbf{X}_{5}\right)$ & Evening $\left(\mathbf{X}_{6}\right)$ & \\
\hline \multicolumn{8}{|l|}{ Kharif season, 2015-16 } \\
\hline Thrips & -0.305 & $-0.475 *$ & $-0.588 * *$ & $-0.603 * *$ & 0.259 & -0.051 & 0.076 \\
\hline Nesidiocoris tenuis Reuter & 0.060 & $-0.654 * *$ & $-0.573 * *$ & $-0.568 * *$ & $-0.550 *$ & $-0.707 * *$ & 0.106 \\
\hline Disease incidence (\%) & -0.029 & $-0.717 * *$ & $-0.521 *$ & $-0.523 *$ & -0.325 & $-0.600 * *$ & 0.098 \\
\hline \multicolumn{8}{|l|}{ Kharif season, 2016-17 } \\
\hline Thrips & $-0.485 *$ & $-0.605 * *$ & 0.215 & 0.00 & 0.230 & -0.099 & -0.301 \\
\hline Nesidiocoris tenuis Reuter & 0.291 & 0.056 & 0.033 & 0.00 & $-0.512 *$ & $-0.671 * *$ & 0.333 \\
\hline GBNV disease disease (\%) & 0.188 & -0.031 & -0.004 & 0.00 & $-0.480 *$ & $-0.689 * *$ & 0.387 \\
\hline
\end{tabular}

$*$ Significance at $\mathrm{p}=0.05 ; * *$ significance at $\mathrm{p}=0.01$

Table.3 Multiple regression equations for thrips, GBNV disease and Nesidiocoris with different weather parameters

\begin{tabular}{|c|c|c|}
\hline Particulars & Regression equation & $\mathbf{R}^{2}$ Value \\
\hline \multicolumn{3}{|l|}{ Kharif, 2015-16 } \\
\hline Total thrips & $\begin{array}{l}Y=2.673-0.024 X_{1}-0.132 X_{2}+0.059 X_{3}-1.980 X_{4}+0.013 X_{5}+0.035 \\
X_{6}+0.110 X_{7}\end{array}$ & 0.803 \\
\hline $\begin{array}{l}\text { Nesideocoris tenuis } \\
\text { Reuter }\end{array}$ & $Y=5.618+0.056 X_{1}-0.134 X_{2}+0.097 X_{3}-2.324 X_{4}-0.022 X_{5}-0.008 X_{6}-0.072 X_{7}$ & 0.712 \\
\hline Disease incidence (\%) & $\begin{array}{l}Y=86.791+1.540 X_{1}-4.316 X_{2}+3.744 X_{3}-83.920 X_{4}-0.176 X_{5}-0.168 X_{6^{-}} \\
0.570 X_{7}\end{array}$ & 0.609 \\
\hline \multicolumn{3}{|l|}{ Kharif, 2016-17 } \\
\hline Total thrips & $Y=16.296-0.298 X_{1}+0.007 X_{2}-0.013 X_{3}+0.00 X_{4}-0.002 X_{5}-0.073 X_{6}-0.025 X_{7}$ & 0.649 \\
\hline $\begin{array}{l}\text { Nesideocoris tenuis } \\
\text { Reuter }\end{array}$ & $Y=14.153-0.250 X_{1}+0.137 X_{2}-0.009 X_{3}+0.00 X_{4}-0.013 X_{5}-0.096 X_{6}-0.224 X_{7}$ & 0.617 \\
\hline $\begin{array}{l}\text { GBNV disease incidence } \\
(\%)\end{array}$ & $\begin{array}{l}Y=358.983-8.516 X_{1}+2.868 X_{2}+0.476 X_{3}+0.00 X_{4}-0.493 X_{5}-2.092 X_{6^{-}} \\
0.778 X_{7}\end{array}$ & 0.750 \\
\hline
\end{tabular}


Fig.1 Population dynamics of thrips on tomato Kharif (2015-16)

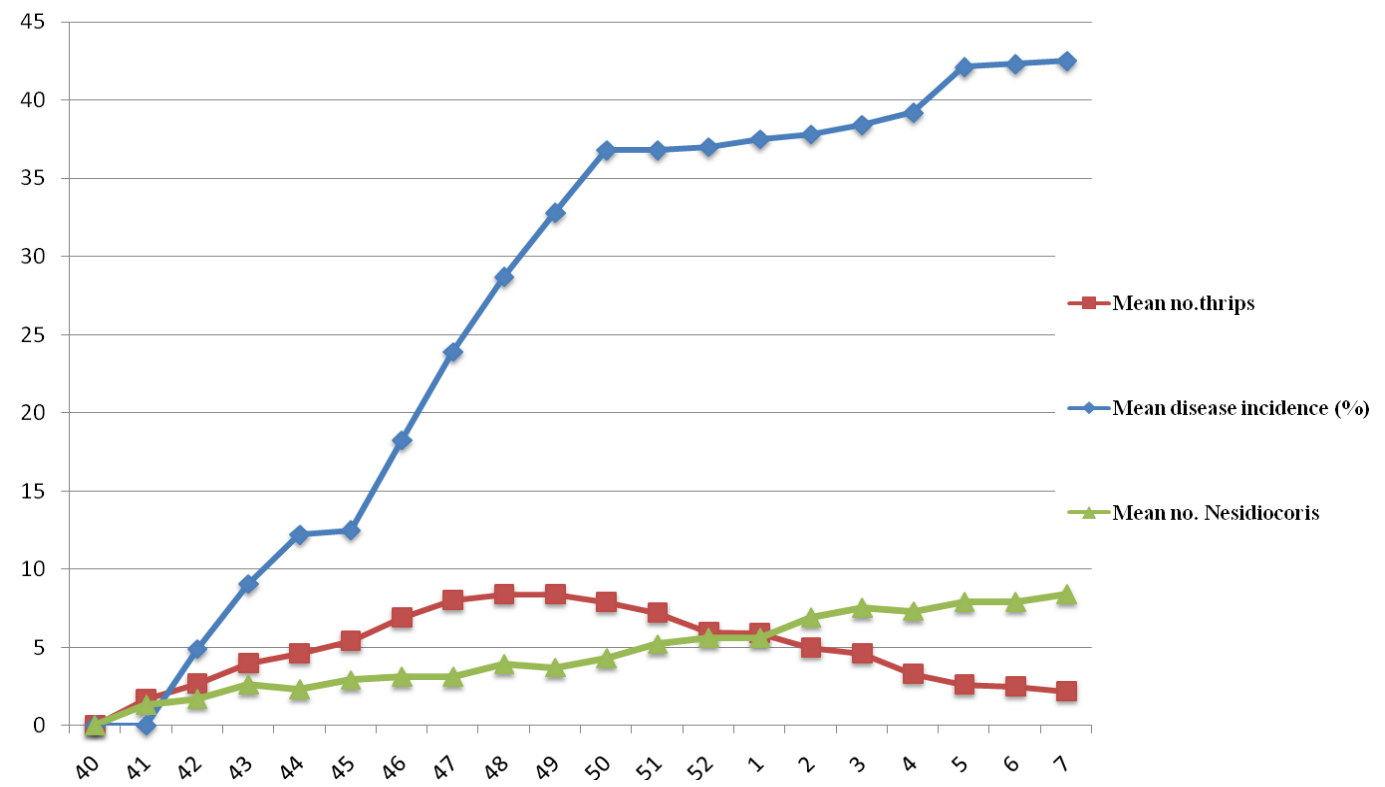

Observation at different standard weeks

Fig.2 Population dynamics of thrips on tomato Kharif (2016-17)

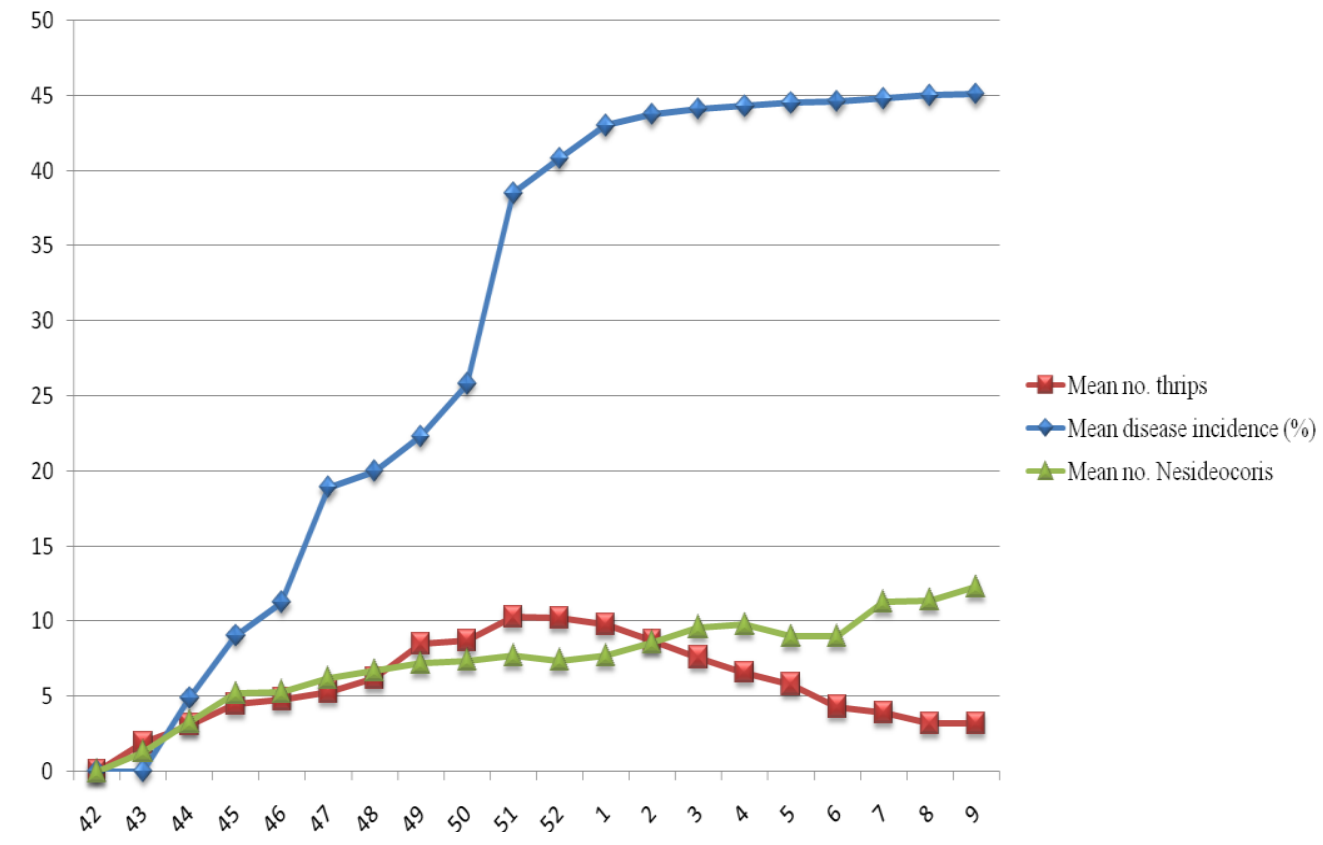

Observation at different standard weeks

The minimum temperature $(\mathrm{r}=-0.717)$ and evening relative humidity $(\mathrm{r}=-0.600)$ shown highly significant negative correlation with thrips population. The maximum temperature and sunshine hours found non significant negative and positive correlation respectively. Similarly during 2016-17, evening relative humidity $(r=-0.689)$ was highly significant 
and negatively correlated, but minimum temperature and rainfall were non significant and negatively correlated.

These findings are in agreement with the earlier reports which reveals, the higher thrips population in chilli was noticed during post rainy season (December to March) (Borah, 1987; Hosamani et al., 2007) and significant negative correlation was observed between tomato thrips with minimum temperature $(\mathrm{r}=-$ $0.524)$, evening relative humidity $(\mathrm{r}=-0.566)$ and rainfall $(\mathrm{r}=-0.453)$ Subba and Ghosh (2016). Minimum temperature, morning and evening relative humidity and sunshine hours were negatively correlated with thrips in onion (Vijayalakhsmi et al., 2017). In contrary to this minimum temperature, morning relative humidity were positively correlated with thrips population in tomato (Ruth, 2010), deviation might be due to the different planting time and prevailed weather conditions during the study period.

Increased $N$. tenuis population could be the other reason for thrips decline, the miridbug population shown significant positive correlation with thrips population. These findings were in conformity with the findings of Hinomoto et al., (2015) who reported that, $N$. tenuis significantly reduced the $T$. tabaci population on onion under protected greenhouse in Japan. $N$. tenuis significantly reduced the thrips, $F$. occidentalis population in sweet pepper (Sarra et al., 2018).

The cumulative mean disease incidence of GBNV was $42.50 \%$ and $45.10 \%$ during 2015-16 and 2016-17 respectively (Figure 1 and 2), it may be due to gradual decrease in rainfall and evening temperature (21.8 to $18.90 \mathrm{C}^{\circ}$ and 16.70 to $13.80 \mathrm{C}^{\circ}$ ) during later stage of the crop. These findings are on par with the earlier reports, where the higher incidence of GBNV disease in chilli and groundnut were more during post rainy season (Hosamani, 2007; Vijayalakshmi, 1994)

Summary and conclusions are as follows:

The studies on population dynamics of thrips and bud necrosis disease on tomato crop, indicated that, the thrips activity found throughout the cropping period. The population of thrips was more during flowering and fruiting stage later it was decreased as crop matures. During 2015-16 kharif crop, maximum thrips population $(8.40$ thrips/three leaves) was observed during the last week of November and first week of December. Similarly during 2016-2017 kharif crop, maximum thrips population (10.30 thrips/three leaves) was observed during third and last week of December.

The population of zoopytophagous miridbug, Nesidiocoris tenuis Reuter was found linear with the population of thrips during both the seasons.

The mean disease incidence of GBNV was directly proportional to the mean number of thrips. The cumulative disease incidence $42.50 \%$ and $45.10 \%$ was observed during 2015-16 and 2016-17 kharif crops respectively.

Correlation studies indicated that, the minimum temperature, rainfall and evening relative humidity were found significant negative correlation, whereas the sunshine hours and morning relative humidity found significant positive correlation with the thrips population and GBNV disease incidence.

\section{Acknowledgement}

Authors would like to thank University Grant Commission for providing the scholarship during the study period. Also thank Dr. N. M, Meshram Senior scientist, Division of 
Entomology ICAR-IARI, New Delhi for the miridbug, Nesidiocoris tenuis Reuter identification.

\section{References}

Anjaneya Reddy, B., Krishna Reddy, M., Jalali, S., Patil, M. S. and Usharani, T. R., 2008, Detection of a tomato tospovirus infecting (Solanum lycopersicon). Indian J. Virol., 19(1): 32-35.

Bikash Subba and Ghosh, S.K., 2016. Population dynamics of thrips (Thrips tabaci 1.) Infesting tomato and their sustainable management, International Journal of Agricultural Science and Research, 6(3) 473-480.

Borah, D.C., 1987, Bio-ecology of Polyphagotarsonemus latus (Banks) (Acari: Tarsonemidae) and Scirtothrips dorsalis Hood (Thysanoptera: Thripidae) infesting chilli and their natural enemies. Ph. D. Thesis, Univ. Agric. Sci., Dharwad, Karnataka (India).

Fenderburk, J.E., Gobrt, D. W., Teare I. D. and Stanvusky, T., 1996, Thrips injury can reduce yield and quality under conditions of multiple stress. Agron. J., 90: 563-566.

Ghawande, M. P., 1983, Effect of cultural practices on the disease (bud necrosis, collar rot, stem rot) incidence and yield of groundnut. Indian Botanical Reporter 2:176-177.

Hemalatha., 1999, Detection and transmission of Tomato Necrotic Spot Tospovirus (TNSV) infecting tomato (Lycopersicon esculentum Mill.) M. Sc (Agri) Thesis Uni. Agric. Sci., Bengaluru, Karnataka (India).

Hosamani, A., 2007, Management of chilli murda complex in irrigated ecosystem. Ph.D. Thesis. Uni. Agric. Sci., Dharwad, Karnataka (India).
Krishnaveni, D., 1998. Studies on Tomato Spotted Wilt Virus (TSWV). Ph.D. Thesis, Acharya N.G. Ranga Agri. Univ., Rajendranagar, Andhra Pradesh (India).

Hinomoto, N., Nagasaka,K., Goto, C., Kohara, S. and Tezuka, T. 2015. Biological Control of Thrips tabaci by Omnivorous Predator, Nesidiocoris tenuis on Cucumbers in Greenhouses. Annual Report of the Kanto-Tosan Plant Protection Society, No. 62, 2015.

Latha, H., and Hunumanthraya, L., 2018. Screening of chilli genotypes against chilli thrips (Scirtothrips dorsalis Hood) and yellow mite, Polyphagotarsonemus latus (Banks). Journal of Entomology and Zoology Studies, 6 (2): 2739-2744.

Mandal, B., Jain, R. K., Krishnareddy, M., Krishna Kumar, N. K., Ravi, K. S. and Pappu, H. R., 2012, Emerging problems of tospoviruses (Bunyaviridae) and their management in the Indian subcontinent. Plant Dis., 96: 468-479.

Manjunatha, L., 2008. Studies on bud blight disease of tomato caused by Groundnut bud necrosis virus. M. Sc (Agri). Thesis, Univ. Agri. Sci., Dharwad, Karnataka (India).

Mound, L., 2002. So many thrips - so few tospoviruses? Thrips and Tospoviruses: Proceedings of the 7th International Symposium on Thysanoptera, Canberra: Australian National Insect Collection CSIRO, 2002.

Ravi, K. S., Kitkaru, A.S., and Winter, S., 2006. Iris yellow spot virus in onions: A new tospovirus record form India. Plant Pathol., 55:288.

Reddy, D.V.R., Amin, P. W., Donald, M. and Ghanekar, A. M., 1983. Epidemiology and control of groundnut bud necrosis 
and other diseases of legume crops in India caused by Tospoviruses. Plant virus epidemiology, pp. 903-1002.

Ruth, C., 2013. Molecular characterization and management of bud necrosis virus infecting tomato in Andhra Pradesh, Ph.D. Thesis, Acharya N.G. Ranga Agri. Univ., Rajendranagar, Andhra Pradesh (India).

Sarra, B., Alberto U., and Pérez-Hedo, M., 2018. Comparative biocontrol potential of three predatory mirids when preying on sweet pepper, Biological Control, Vol.121. 168-174

Singh, S.J., and Reddy, K. M., 1996, Watermelon Bud Necrosis Virus disease: A new tospovirus disease. Acta Hort., 431: 68-77.

Sridhar, V., Jayashankar, M., and Vinesh, L. S., 2012. Population dynamics of zoophytophagous Nesidiocoris tenuis (Reuter) (Heteroptera: Miridae) and its prey, Bemisia tabaci Genn. (Homoptera:
Aleyrodidae) on tomato. Pest management in Horticultural Ecosystems, 18, 35-38.

Van der Plank, J.E., 1963. Plant diseases: Epidemics and Control, Academic press, New York, London.

Vijayalakshmi, K., 1994. Transmission and ecology of Thrips Palmi Karny, The vector of Peanut bud Necrosis Virus, Ph.D. Thesis. Acharya N. G. Ranga. Agri. Univ., Rajendranagar Andhra Pradesh (India).

Vijayalakshmi, G., Ganapathy, $\mathrm{N}$ and Kennedy, J. S., 2017. Influence of weather parameters on seasonal incidence of thrips and Groundnut Bud Necrosis Virus (GBNV) in groundnut (Arachis hypogea L.). J. Entomology and Zoology Studies, 5(3): 107-110.

Whitfield, A.E., Ullman, D. E. and German, T. L., 2005. Tospovirus-thrips interactions. Annu. Rev. Phytopathol., 43: 459-489.

\section{How to cite this article:}

Jamuna, B., M. Bheemanna, A.C. Hosamani, V.N. Ghante, M.R. Govindappa, K. Kavitha and B. Kisan. 2019. Population Dynamics of Thrips and Bud Necrosis Virus Disease on Tomato. Int.J.Curr.Microbiol.App.Sci. 8(05): 24-34. doi: https://doi.org/10.20546/ijcmas.2019.805.004 